\title{
Phenological Studies of High Value Endangered Medicinal Herbs: Picrorhiza kurroa and Saussurea costus in Sub-alpine Regions of Garhwal Hiamalya, Uttarakhand India
}

\author{
Anand Singh Bisht, Rajendra Singh Chauhan \\ Department of Plantation, Spices, Medicinal and Aromatic Plants, VCSG Uttarakhand University of \\ Horticulture and Forestry, Bharsar Uttarakhand, 246123, India
}

*Corresponding Author: Anand Singh Bisht, Department of Plantation, Spices, Medicinal and Aromatic Plants, VCSG Uttarakhand University of Horticulture and Forestry, Bharsar Uttarakhand, 246123, India

\begin{abstract}
The study of various periodic behaviours of plant species or the phenology has great significance because it not only provides knowledge about the plant growth pattern but also provides the inferences on the effect of environment and selective pressure on flowering and fruiting behaviour. In this paper an attempt has been made to record such data regarding periods of leaf fall, leaf flushing, flowering, fruiting and all. This was done for a period of three years for two species viz. Picrorhiza kurroa and Saussurea costus of course which were somehow having medicinal properties. In the study the leaf fall peak period was found in last part of December, leaf flushing peak period in the month of march where as flowering and fruiting activity peak period was found during the month of April-May and July-August respectively. So, this type of study will be helpful to give inferences in future whether the of climate change are giving pressure on the periodic behaviour of plant species.
\end{abstract}

Keywords: Phenology, leaf fall, leaf flush, flowering, fruiting, Garhwal Himalaya.

\section{INTRODUCTION}

In nature it is often seen that each species has a definite period, month, season in a year during which its seeds germinate, seedlings grow or show maximum vegetative growth, leaves fall (if it is deciduous), flushing of new leaves, flowering and then fruiting. The study of all these periodic behaviour of a species is called its phenology. In the life cycle of a plant each and every stage is greatly influenced by a number of environmental factors. The different stages of the plant species remain completely embedded in an environmental complex. It is very interesting to note that being fixed at a particular place, the requirement of germination, growth, flowering, fruiting, leaf fall, etc. of the species are met with at the same place but of course in different times of the year. There is a synchronization of phenological behaviour of the species and the various factors of the environment that plants are spoken of biological clocks. This is mostly regulated by external signals from the environment. But the interactions of each and every species are different at different stages of their life cycle. Thus plant phenological study has great significance because it not only provides knowledge about the plant growth pattern but it also provides the idea on the effect of environment and selective pressure on flowering and fruiting behavior (Zhang et al 2006).

\subsection{About Picrorhiza kurroa}

Picrorhiza kurroa Royle ex Benth. (Family: Scrophulariaceae) native to Western Himalayan region, between 3000-5000m elevation (Hooker 1885; Agrawal 2003) is valued as hepato-protective, antiperiodic, cholagouge, and stomachic, antiamoebic, anti-oxidant expectorant, etc. (Singh et al 2006). The rhizome of Picrorhiza has been traditionally used to treat worms, constipation, low fever, scorpion sting, asthma and ailments affecting the liver. Picrorhiza kurroa also known as kutki is found in the North-Western Himalayan region from Kashmir to Kumaun and Garhwal regions in India.

Kutkin is the active principal of Picrorhiza kurroa and is comprised of kutkoside and the iridoid glycoside picrosides I, II, and III. Other identified active constituents are apocynin, drosin, and nine cucurbitacin glycosides (Stuppner and Wagner 1989). Apocynin is a catechol that has been shown to 
inhibit neutrophil oxidative burst in addition to being a powerful anti-inflammatory agent, while the curcubitacins have been shown to be highly cytotoxic and possess antitumor effects (Simons et al 1990).

\subsection{About Saussurea costus}

Saussurea costus (Family: Asteraceae) is an erect, robust, pubescent, perennial herb, with a stout simple stem 1-2 m high. Leaves membranous, scaberulous above, glabrate beneath, auricled at base, irregularly toothed; basal ones very large, $0.50-1.25 \mathrm{~m}$ long, with a long winged petiole; upper leaves smaller, subsessile or shortly petioled; two small lobes at the base of these leaves almost clasping the stem. Flower heads stalkless, bluish-purple to almost black, hard, rounded, 2.4-3.9 cm across, often 25 clustered together in the axils of leaves or terminal. Involucral bracts many, ovate-lanceolate, long pointed, purple, rigid, hairless. Receptacle bristles very long. Corolla about $2 \mathrm{~cm}$ long, tubular, bluepurple or almost black. Anther tails fimbriate. Achenes curved compressed ca. $8 \mathrm{~mm}$ long, tip narrowed, with one rib on each face. Pappus brown, double feathery. Roots are stout, dark brown or grey, up to $40 \mathrm{~cm}$ long (Hajra et al., 1995). Upadhyay et al. (1993) have described the macro and microscopical characters of the roots of Saussurea costus while Saklani et al. (2000) have reported its achene morphology. Several workers (Gupta, 1964; Hajra, 1988; Hajra et al., 1995; Chaudhary and Rao, 2000) have significantly contributed towards the morphological characterization of the genus Saussurea in India, including Saussurea costus. Macromorphological parameters like habit, size of plants, size and shape of leaves and capitula and the nature of phyllaries in Saussurea costus have been described by all the above workers.

In the Indian systems of medicine Saussurea costus is used either as a single drug or in combination with other drugs. Its roots are used mainly as an antispasmodic in asthma, cough and also in treatment of cholera, chronic skin diseases and rheumatism (Chopra et al., 1956; Dhar et al., 1984). Its different preparations are also used by Ayurvedic physicians for the treatment of various ailments like cough and cold, quartan malaria, leprosy, persistant hiccups, rheumatism, hair-wash, stomachache, toothache, typhoid fever, etc. It is an important medicine for gout, erysipelas and promotes spermatogenesis. Saussurea costus has been used by different peoples and ethnic tribes of the Northern parts of India for the treatment of various ailments. The roots are also used in Tibetan medicine where it is considered to have an acrid, sweet and bitter taste with a neutral potency. Several traditional Tibetan formulae that are used for chronic inflammation of the lungs, cough, and chest congestion Hippophae 5, eliminator of lung inflammation contain Saussurea as one of the important ingredients (Tsarong, 1994).

\section{Materials AND Methods}

\subsection{Study Area}

In general, the climate of the Bharsar represents mild summer, higher precipitation and prolonged cold winter season. The climatic factors such as precipitation, temperature, relative humidity and wind, in association with elevation, slope aspects, drainage, vegetation, etc. are responsible for the micro-climate of this area. Generally, days of Bharsar are fairly warm followed by cool nights. The area receives adequate sunshine hours whereas the growing period is shorter due to long winter. The area also receives heavy precipitation during monsoon and occasional snow fall during winter season. The mean monthly weather data for one year is presented in Figure 1.

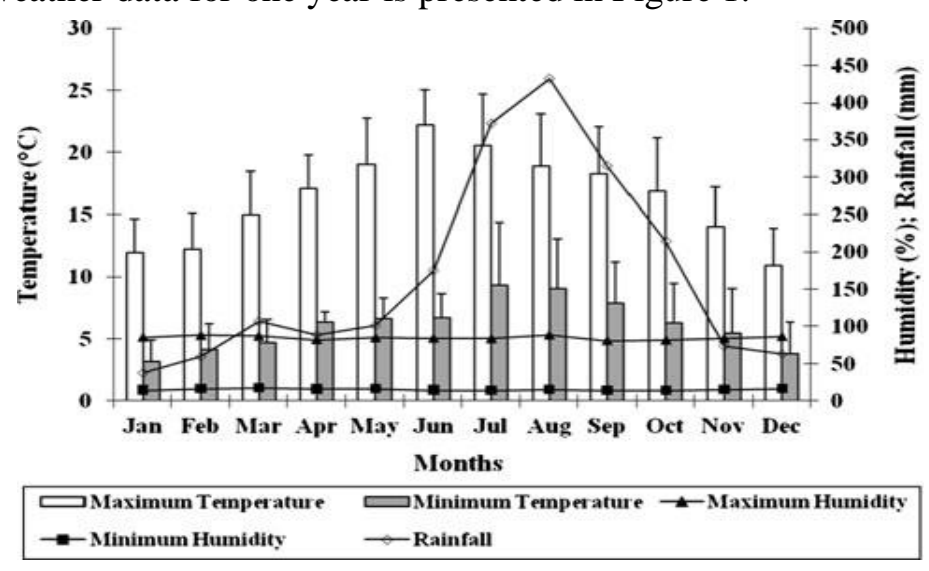

Fig1. Meteorological data of the study area 
The phenological study was carried out for two species of medicinal plants in the field of MAP block VCSG UUHF Bharsar. Observation was made on leaf fall, leaf flushing, flowering, and fruiting at one month of interval between January 2012 to December 2014.

\section{RESULTS AND DISCUSSION}

After observation a record of time period of leaf fall, leaf flushing, flowering and fruiting were prepared for the both species of medicinal plants in a tabular form for the period of three years. Then the data were analyzed from which some important inferences were made.

\subsection{Leaf Fall and Leaf Flushing Activity}

The leaves of the plant are flat, oval, and sharply serrated. After the data analysis it was found that leaf fall initiation was a periodic activity of the species. Both the species leaf fall started in the month of November/December with a peak in the last part of January (30\%) to first part of February (50\%). Most of the leaves are dried after yellowing and remain persistent on parent plant. After shedding or drying of older leaves during winter new leaf initiation starts with increasing in temperature in next growing season in the species, the time period of this activity seen to be different in different species. But it can be said that sprouting new leaf started in the month of February $(25 \%)$ continued upto May $(30 \%)$ with a peak in the month of March (50\%) that is before the outset of monsoon.

\subsection{Flowering Activity}

The flowers, which appear March onwards, are white or pale purple and born on a tall spike in Picrorhiza. In Saussurea costus flowering start in the month of April. However, peak period of flowering can be distinguished for the species in the month of July-August.

\subsection{Fruiting Activity}

After flowering both the species start fruiting. The peak period of maturation of fruit was May-June in P. kurroa and July to August Saussurea costus.

Table1.Calendar for reproductive phase in P. kurroa

\begin{tabular}{|c|l|c|l|}
\hline S. no. & \multicolumn{1}{|c|}{ Stages } & Time period (days) & Month (week) \\
\hline A & Young inflorescence & $12-15$ & March $\left(2^{\text {nd }}\right)$ \\
\hline B & Inflorescence with slightly opened buds & $3-4$ & March $\left(4^{\text {th }}\right)$ \\
\hline C & Inflorescence with half opened floral buds & $4-F e b$ & March $\left(3^{\text {rd }}\right)$ \\
\hline D & Inflorescence with fully opened flowers & $3-F e b$ & April $\left(1^{\text {st }}\right)$ \\
\hline E & Immature green capsule & $8-10$ & April $\left(2^{\text {nd }}\right)$ \\
\hline F & Mature capsule & $15-20$ & April $\left(4^{\text {th }}\right)$ \\
\hline G & Close up of mature capsule & $20-25$ & May $\left(3^{\text {rd }}\right)$ \\
\hline H & Capsule ready to dehisce & $7-10$ & June $\left(1^{\text {st }}\right)$ \\
\hline I & Fully mature dry capsule & $7-10$ & June $\left(2^{\text {nd }}\right)$ \\
\hline
\end{tabular}

Table2.Calendar for reproductive phase in Saussurea costus

\begin{tabular}{|l|l|r|r|}
\hline S. no. & \multicolumn{1}{|c|}{ Stages } & Time period (days) & \multicolumn{1}{c|}{ Month (week) } \\
\hline A & Young inflorescence & $25-35$ & May $\left(1^{\text {st }}\right)$ \\
\hline B & Inflorescence with slightly opened florets & $15-20$ & May $\left(3^{\text {rd }}\right)$ \\
\hline C & Inflorescence with half opened florets & $10-15$ & June $\left.^{\left(1^{\text {st }}\right.}\right)$ \\
\hline D & Inflorescence with fully composite flowers & $15-20$ & June $\left.^{\text {nd }}\right)$ \\
\hline E & Fully mature dry inflorescence (achene) & $20-25$ & July-August \\
\hline F & Seed & $10-20$ & July-August \\
\hline G & Germination (\%) of seeds & 80 & \\
\hline H & Days from bud formation to seed set & 150 & \\
\hline
\end{tabular}

The phenology and growth of the plants changes with the increase in altitude due to alteration in assimilate investment patterns and metabolism, thereby affecting their growth (Korner and Renhard 1987). Low temperature and high light intensity at higher altitudes are responsible for small height of plants besides having small leaves with thicker lamina. Low temperature at high altitudes also results in low growth rate in alpine plants species by reducing rate of nitrogen mineralization in soil and uptake of nitrate by plants (Bowman et al 1995; Seastedt et al 2001). Leaf area, respiration rate, 
Phenological Studies of High Value Endangered Medicinal Herbs: Picrorhiza kurroa and Saussurea costus in Sub-alpine Regions of Garhwal Hiamalya, Uttarakhand India

photosynthesis per unit leaf mass and carbohydrate level play an important role in maintaining growth of many plant species (Pandey et al 2008).

Every step should be taken to conserve the medicinal or other plant diversity of the regions which is already in a critical level that can be justified by observing the present percentage of forest, inclusion of species in red data book or changed phenological behavior of the plant species.

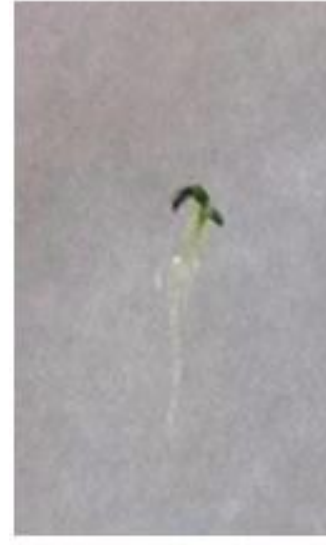

a. Germinated seed

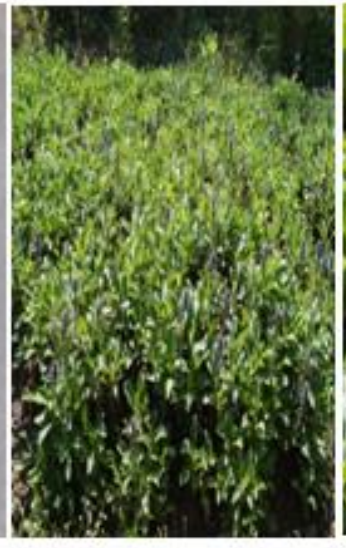

b. Vegetative growth

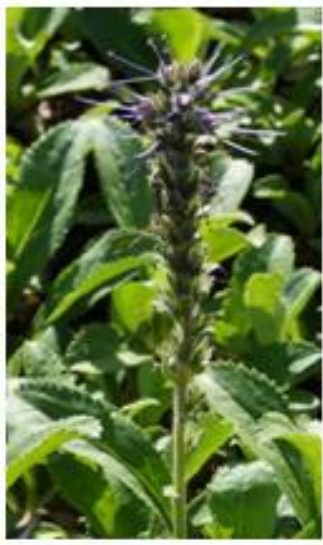

c. Floral part

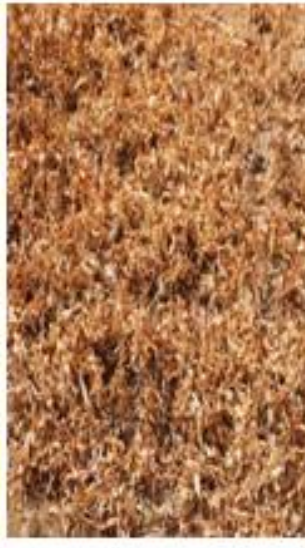

d. Dormancy stage

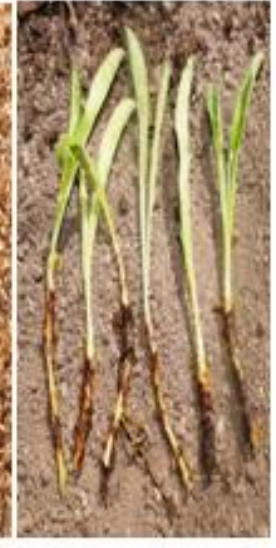

e. Young seedling

Fig1. Picrorhiza kurroa: Different phenolphage

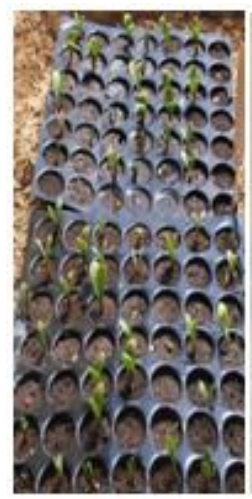

a. Germinated seed

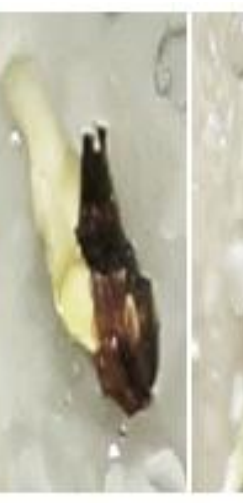

b. Vegetative growth

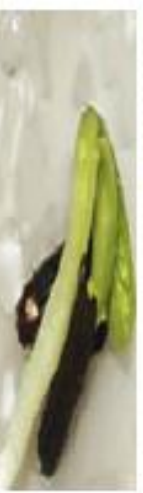

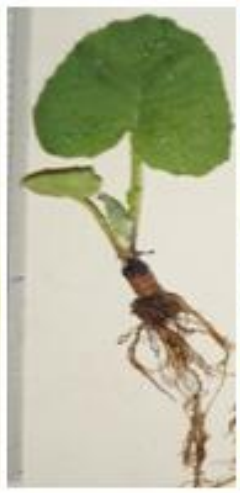

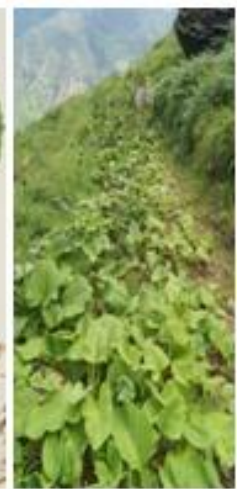

c. Floral stage
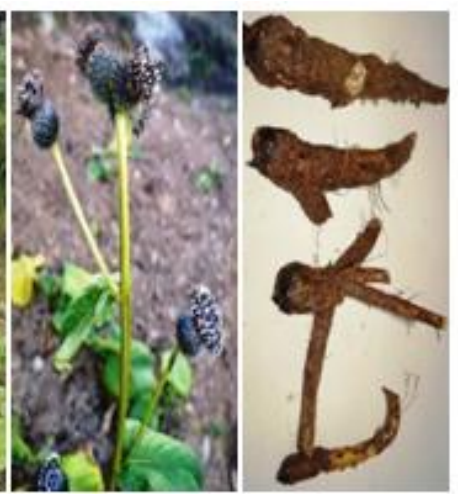

d. Floral part

e. Economic part

Fig2. Saussuria costus: Different phenophage

\section{REFERENCES}

Bisht A.S. (2005). Ecological studies of some important medicinal plant; their multiplication and conservation in Garhwal Himalaya, India. Ph.D thesis submitted HNB Garhwal University Srinagar (Garhwal).

Bisht A.S. (2015). Ecological analysis of Hedychium spicatum Buch in temperate region of Garhwal Himalaya, Uttarakhand. India. Medicinal Plants 7 (2)120-126.

Boojh R, Ramakrishnan PS (1981) Phenology of tree in sub-tropical evergreen montane forest in North eastern India. Geo-Eco-Trap. 5: 189-209.

Bowman W D, Theodase T A and Fisk M C (1995) Physiological and Production responses of plant growth forms to increase in limiting resources in alpine Tundra; Implication for differential communities response to environmental change, Oecologia, 110:217-227.

Butola J.S and A.R. Malik (2012). Phenology and Survival of some Himalayan medicinal plants domesticated at different altitudes. Int. J. Med. Arom. Plants 2 (4) 683-687.

Chaudhary, H.J., Rao, R.R., (2000). Trans-Himalaya: a vast genetic resource centre of less known economic plants. Indian Journal of Forestry 23, 446-456.

Gupta, R., (1964). Survey record of medicinal and aromatic plants of Chamba forest division, Himachal Pradesh. Indian Forester 90, 454-463.

Hajra, P.K., (1988). Brahmkamal and Its Allies (the genus Sassurea). Jugal Kishore and Co., Dehradun, India.

Hajra, P.K., Rao, R.R., Singh, D.K., Uniyal, B.P., (1995). Flora of India, vol. 12.BSI, Calcutta, p. 187. 
Phenological Studies of High Value Endangered Medicinal Herbs: Picrorhiza kurroa and Saussurea costus in Sub-alpine Regions of Garhwal Hiamalya, Uttarakhand India

Hooker, J.D., (1881). Flora of British India, vol. 3. L. Reeve and Co., London

Korner C and Renhardt U (1987). Dry matter portioning and root length/ leaf area ratio in herbaceous perennial plants with diverse altitudinal distribution, Oecologia. 74: 411-418.

Opler PA, Frankie GW, Baker HG (1980). Comparative phenological studies of treelet and shrub species in tropical Wet and Dry forests in the low lands of Costa Rica. J. of Ecobiology, 68: 167-188.

Pandey M.M, S. Rastogi, A. K. S. Rawat (2007). Saussurea costus: Botanical, chemical and pharmacological review of an ayurvedic medicinal plant. Journal of enthenopharmacology. 110:379-390.

Pandey S., S. Malik, S. Sharma and M. Sharma (2008). Studies on differential growth behavior of two alpine herbs of Western Himalaya from different altitudes under in vitro conditions. Indian journal of Biotechnology, 7:137-140.

Saklani, A., Rao, R.R., Chaudhary, L.B., (2000). SEM Characterizations of achene morphology towards the taxonomy of Indian sp. of Saussurea D.C. Rheedea10:1-18

Seastedt T R and Vaccaro L. (2001). Plant species richness, productivity and nitrogen and phosphorus limitation across a snowpack gradient in alpine Tundra, Colorado USA, Arct Antract Alp Res. 33: 100-106.

Simons JM, Hart BA, Vai Ching TR, (1990). Metabolic activation of natural phenols into selective oxidative burst agonists by activated human neutrophils. Free Radic Biol Med 8:251-258.

Singh KP, Kushwaha CP. (2005). Emerging paradigms of tree phenology in Dry Tropics. Current Sci. 89: 964975.

Stuppner H, Wagner H. (1989). New cucurbitacin glycosides from Picrorhiza kurroa. Planta Med; 55:559-563.

Upadhyay, O.P., Ojha, J.K., Datta, S.K., (1993). Pharmacognostic study of the root of Saussurea lappa C.B. Clarke. Sachitra Ayurveda 8, 608-612.

Worral J. (1993). Temperature effects on bud burst and leaf fall in sub-alpine larch. Journal of Sustainable forestry 1:1-18.

Woodward F. I. (1986). Ecophysiological studies on the shrub Vaccinium myreillus L. taken from a wide altitudinal range Oecologia, 70:580-586.

Zhang G., Song Q, Yang D. (2006). Phenology of Ficus racemosa in Xishungbanna, South west China. Biotropica. 38: $334-341$.

Citation: A. Bisht \& Rajendra Singh Chauhan, "Phenological Studies of High Value Endangered Medicinal Herbs: Picrorhiza kurroa and Saussurea costus in Sub-alpine Regions of Garhwal Hiamalya, Uttarakhand India", International Journal of Medicinal Plants and Natural Products (IJMPNP), vol. 4, no. 1, pp. 8-12, 2018. http://dx.doi.org/10.20431/2454-7999.0401002

Copyright: (C) 2018 Authors. This is an open-access article distributed under the terms of the Creative Commons Attribution License, which permits unrestricted use, distribution, and reproduction in any medium, provided the original author and source are credited. 